\title{
Dynamics of benthic copepods and other meiofauna in the benthic boundary layer of the deep NW Mediterranean Sea
}

\author{
L. D. Guidi-Guilvard ${ }^{1,2, *}$, D. Thistle ${ }^{3}$, A. Khripounoff ${ }^{4}$, S. Gasparini ${ }^{1,2}$ \\ ${ }^{1}$ CNRS, and ${ }^{2}$ Université Pierre et Marie Curie, Laboratoire d'Océanographie de Villefranche, 06234 Villefranche/Mer, France \\ ${ }^{3}$ Department of Oceanography, Florida State University, Tallahassee, Florida 32306-4320, USA \\ ${ }^{4}$ IFREMER centre de Brest, Laboratoire Environnement Profond, 29280 Plouzané, France
}

\begin{abstract}
A continuous high-resolution time-series survey of the hyperbenthic community and local environmental conditions was conducted in the benthic boundary layer (BBL) of the DYFAMED-BENTHOS station $\left(43^{\circ} 24.61^{\prime} \mathrm{N}, 7^{\circ} 51.67^{\prime} \mathrm{E}\right.$ at $2347 \mathrm{~m}$ depth in the NW Mediterranean) between January 1996 and April 1998 using bottom-moored sediment traps and a current meter. Sediment traps were set $4 \mathrm{~m}$ above the bottom. Hyperbenthos was collected as 'swimmers', i.e. those organisms that are alive when they enter the traps but are not part of the particle flux. Identification of these organisms showed that $~ 90 \%$ were meiobenthic. Copepods dominated and comprised on average $75 \%$ of total swimmers. They were followed by nauplii $(12 \%)$, annelids $(7.8 \%)$, nematodes and bivalves (1.8\% each), ostracods, isopods, and amphipods (1.2\% altogether). Of the 3930 copepods examined, $4 \%$ were calanoids, $15 \%$ were harpacticoids and $81 \%$ were cyclopoids. Among the non-calanoid copepods, 25 species or groups of species were distinguished. Two benthic copepod species outnumbered all others: the cyclopinid genus Barathricola represented $90 \%$ of the cyclopoids, and the tisbid genus Tisbe represented $57 \%$ of the harpacticoids. Temporal variations, both intra- and interannual, in swimmer fluxes were high (26 to 361 ind. $\mathrm{m}^{-2} \mathrm{~d}^{-1}$ ), but not all groups/ taxa/species were equally affected. Statistical analyses showed that these variations were the result of variability in both physical (near-bottom current) and trophic (particle flux) environmental factors. Organisms had both immediate and delayed responses, which involved passive (i.e. erosion, suspension) and active (i.e. emergence) reactions, as well as population growth. Most of the dispersal mechanisms previously reported for shallow-water benthic organisms were encountered, denoting the remarkable similarities in the general processes between coastal and deep-sea environments.
\end{abstract}

KEY WORDS: Deep sea $\cdot$ Swimmers $\cdot$ Hyperbenthos $\cdot$ Benthic storms $\cdot$ Resuspension $\cdot$ Emergence Population growth $\cdot$ Biodiversity

Resale or republication not permitted without written consent of the publisher

\section{INTRODUCTION}

In the past several decades, there has been a considerable increase in knowledge about the functioning of open oceans, from surface waters to the deep-sea floor. Time-series observations with sediment traps, which collect material as it settles through the water column, have demonstrated that seasonal and episodic varia- tions in surface productivity result in highly variable amounts of organic matter arriving at the seafloor (e.g. Karl et al. 2003), which is moreover subject to variable hydrodynamic conditions (e.g. Lampitt et al. 2001). The rapid delivery of fresh organic material to the deep-sea floor has important implications for life cycles of the benthos. In the food-limited deep sea, the abundance and biomass of benthic organisms depend on the 
amount of food reaching the sediment surface (e.g. Gooday 2002). For example, pulses of organic-rich detritus to the seafloor appear to be responsible for seasonal growth and reproduction in some megafaunal invertebrates (Billet et al. in press) and seasonal changes in macrofaunal densities (Drazen et al. 1998), sediment community respiration rates (Smith et al. 2002), bacterial densities (e.g. Lochte 1992), some foraminiferan species densities (Gooday 1988) and sediment geochemistry (Soetaert et al. 1996). But there is still little evidence that metazoan meiofaunal abundances increase following sedimentation events (Kalogeropoulou et al. 2009).

While deep-sea benthic ecology temporal surveys have focused on organisms living on and in the sediment, little attention has been paid within these studies to the invertebrate fauna present in the nearbottom waters. Single time-point investigations have brought insights on community and food-web structure as well as metabolism of these communities (e.g. Bühring \& Christiansen 2001); however, many aspects concerning the ecology of this fauna are still unknown, in particular its dynamics and responses to local environmental variability.

Here we report the first continuous high-resolution time series for more than 2 annual cycles of the small hyperbenthos collected as 'swimmers' in sediment traps set $4 \mathrm{~m}$ above bottom (mab) in the benthic boundary layer (BBL) of the deep NW Mediterranean. Temporal variations of organism fluxes and species composition were analyzed and related to the simultaneously measured environmental variables.

\section{MATERIALS AND METHODS}

Study site. The present study was part of a long benthic time-series, the DYFAMED-BENTHOS survey (Guidi-Guilvard 2002), that was established in 1991 at the DYFAMED permanent station in the NW Mediterranean (Fig. 1) to investigate bentho-pelagic coupling. This $2300 \mathrm{~m}$-deep station is relatively close to land ( $52 \mathrm{~km}$ off Nice, France), but presents many of the characteristics of the open ocean with strong seasonal signals in surface productivity and essentially vertical particle fluxes. It was the site of the French Joint Global Ocean Flux Study (JGOFS) activities (Marty 2002, Karl et al. 2003) and is an ongoing permanent observatory of atmospheric and water column biogeochemical fluxes and processes (www.obs-vlfr.fr/ sodyf/). The DYFAMED benthic site is situated on the side of the lower median fan valley of the Var Canyon. At the site, the terrain is relatively flat with muddy surface sediments (the silt-clay fraction comprises $>94 \%$ of sediment dry weight) derived primarily from pelagic

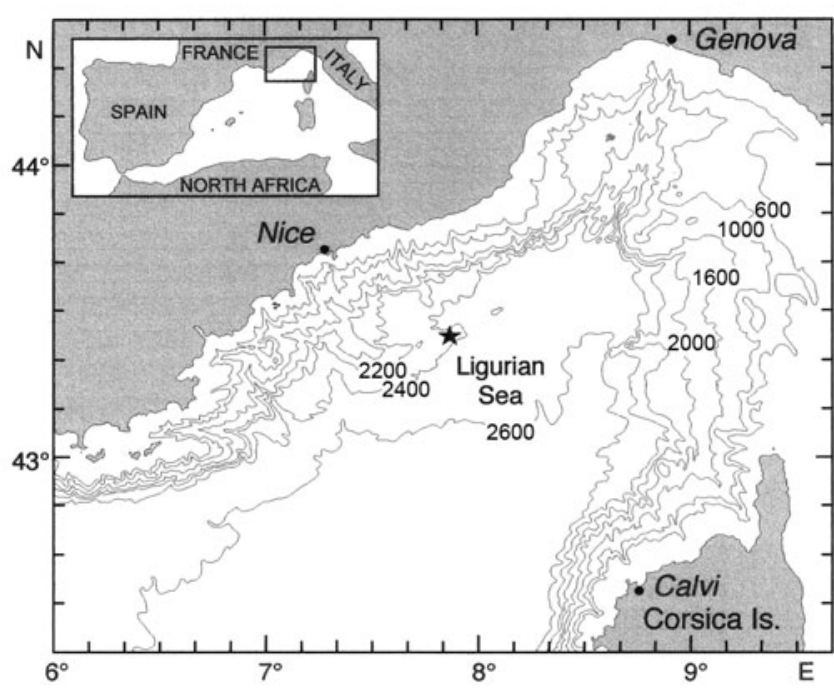

Fig. 1. Ligurian Sea, NW Mediterranean, showing the location of the DYFAMED station (2347 $\mathrm{m}$ depth)

sedimentation. The bottom water temperature is high $\left(12.7^{\circ} \mathrm{C}\right)$, salinity is elevated $(38.4 \%)$ and average dissolved oxygen concentration is $4.7 \mathrm{ml} \mathrm{l}^{-1}$ (GuidiGuilvard 2002).

Sediment traps. The near-bottom sediment-trap mooring was deployed at the DYFAMED benthic site at a bottom depth of $2347 \mathrm{~m}$ (see Guidi-Guilvard 2002). Between January 1996 and April 1998, it was deployed 11 times, i.e. every 1.5 to $3.5 \mathrm{mo}$ (Table 1 ). The mooring included 3 cylindro-conical (cylinder height $50 \mathrm{~cm}$, cone height $60 \mathrm{~cm}$, collection area $0.07 \mathrm{~m}^{2}$, aspect ratio 3.66:1), baffled (cell diameter $10 \mathrm{~mm}$ ), multisample sediment traps (labeled $\mathrm{A}, \mathrm{B}$, and $\mathrm{C}$ ) supported in a rectangular frame (Fig. 2). Each trap had 5 bottles that were rotated under the collecting apparatus at predetermined intervals by a timer. Collection period per bottle varied between 5.5 and $21 \mathrm{~d}($ mean $=14 \mathrm{~d})$. All traps collected particles simultaneously at 4 mab. To inhibit biological activity, bottles were filled with $4 \%$ sodium borate-buffered formaldehyde in filtered seawater. Near-bottom current velocities were determined with an Aanderaa current meter every 120 min at a height of 12 mab until mid-June 1997.

Sample treatment. When the mooring was serviced, the collecting bottles were retrieved and replaced by clean ones. The samples were stored refrigerated. In the laboratory, the contents were gently rinsed with cold filtered seawater on a $100 \mu \mathrm{m}$ sieve. Organisms and particles retained on the sieve were transferred to a Dolfus counting tray and swimmers were identified to the lowest possible taxon, counted and removed under an Olympus SZH dissecting microscope (96x magnification). The specimens were stored in a $4 \%$ buffered formaldehyde-filtered seawater solution until 
Table 1. Station, deployment and sampling data for the near-bottom sediment trap of the DYFAMED station. Sediment traps were equipped with 5 collecting bottles. Abundance of swimmers in each bottle of sediment trap B is indicated in parentheses

\begin{tabular}{|c|c|c|c|c|c|c|c|c|}
\hline \multirow{2}{*}{$\begin{array}{l}\text { Mooring } \\
\text { bottle no. }\end{array}$} & \multirow{2}{*}{ Position } & \multirow[t]{2}{*}{ Start } & \multirow{2}{*}{ Stop } & \multicolumn{5}{|c|}{ No. days per bottle (No. swimmers) } \\
\hline & & & & 1 & 2 & 3 & 4 & 5 \\
\hline Z6 & $43^{\circ} 25.32^{\prime} \mathrm{N}, 07^{\circ} 51.84^{\prime} \mathrm{E}$ & $18 / 01 / 96$ & 04/03/96 & $9(39)$ & $10(18)$ & $10(34)$ & $10(38)$ & $7(22)$ \\
\hline $\mathrm{Z7}$ & $43^{\circ} 25.31^{\prime} \mathrm{N}, 07^{\circ} 51.91^{\prime} \mathrm{E}$ & $06 / 03 / 96$ & $07 / 05 / 96$ & $12(37)$ & $12(31)$ & $12(66)$ & $12(27)$ & $14(73)$ \\
\hline $\mathrm{Z} 8$ & $43^{\circ} 25.26^{\prime} \mathrm{N}, 07^{\circ} 51.88^{\prime} \mathrm{E}$ & 09/05/96 & $22 / 08 / 96$ & $21(177)$ & $21(223)$ & $21(115)$ & $21(73)$ & $21(51)$ \\
\hline $\mathrm{Z9}$ & $43^{\circ} 25.30^{\prime} \mathrm{N}, 07^{\circ} 51.87^{\prime} \mathrm{E}$ & $28 / 08 / 96$ & $12 / 11 / 96$ & $17(82)$ & $15(83)$ & $15(46)$ & 15 (118) & $14(38)$ \\
\hline $\mathrm{Z} 10$ & $43^{\circ} 25.32^{\prime} \mathrm{N}, 07^{\circ} 51.92^{\prime} \mathrm{E}$ & $19 / 11 / 96$ & $11 / 01 / 97$ & $12(105)$ & $12(55)$ & $12(30)$ & $12(76)$ & $5.5(44)$ \\
\hline $\mathrm{Z} 11$ & $43^{\circ} 25.25^{\prime} \mathrm{N}, 07^{\circ} 51.80^{\prime} \mathrm{E}$ & $16 / 01 / 97$ & $08 / 04 / 97$ & 14 (109) & $17(148)$ & $17(152)$ & $17(145)$ & $17(130)$ \\
\hline $\mathrm{Z} 12$ & $43^{\circ} 25.21^{\prime} \mathrm{N}, 07^{\circ} 51.79^{\prime} \mathrm{E}$ & $11 / 04 / 97$ & $16 / 06 / 97$ & $12(86)$ & $12(98)$ & $14(112)$ & $14(95)$ & $14(84)$ \\
\hline $\mathrm{Z} 13$ & $43^{\circ} 25.33^{\prime} \mathrm{N}, 07^{\circ} 51.86^{\prime} \mathrm{E}$ & $18 / 06 / 97$ & $27 / 08 / 97$ & 14 (119) & $14(354)$ & $14(167)$ & 14 (116) & $14(117)$ \\
\hline $\mathrm{Z} 14$ & $43^{\circ} 25.26^{\prime} \mathrm{N}, 07^{\circ} 51.88^{\prime} \mathrm{E}$ & $28 / 08 / 97$ & $05 / 11 / 97$ & $14(184)$ & $14(278)$ & $14(194)$ & 15 (199) & $12(80)$ \\
\hline $\mathrm{Z} 15$ & $43^{\circ} 25.33^{\prime} \mathrm{N}, 07^{\circ} 51.86^{\prime} \mathrm{E}$ & $19 / 11 / 97$ & $18 / 01 / 98$ & $14(46)$ & $14(44)$ & $12(25)$ & $12(81)$ & $8.7(59)$ \\
\hline $\mathrm{Z} 16$ & $43^{\circ} 25.30^{\prime} \mathrm{N}, 07^{\circ} 51.90^{\prime} \mathrm{E}$ & $06 / 02 / 98$ & $15 / 04 / 98$ & $14(125)$ & $14(57)$ & $14(41)$ & $14(51)$ & $12(56)$ \\
\hline
\end{tabular}

analyzed. The swimmer-free particles were immediately transferred back to the corresponding bottles and kept refrigerated. Further processing of the particles

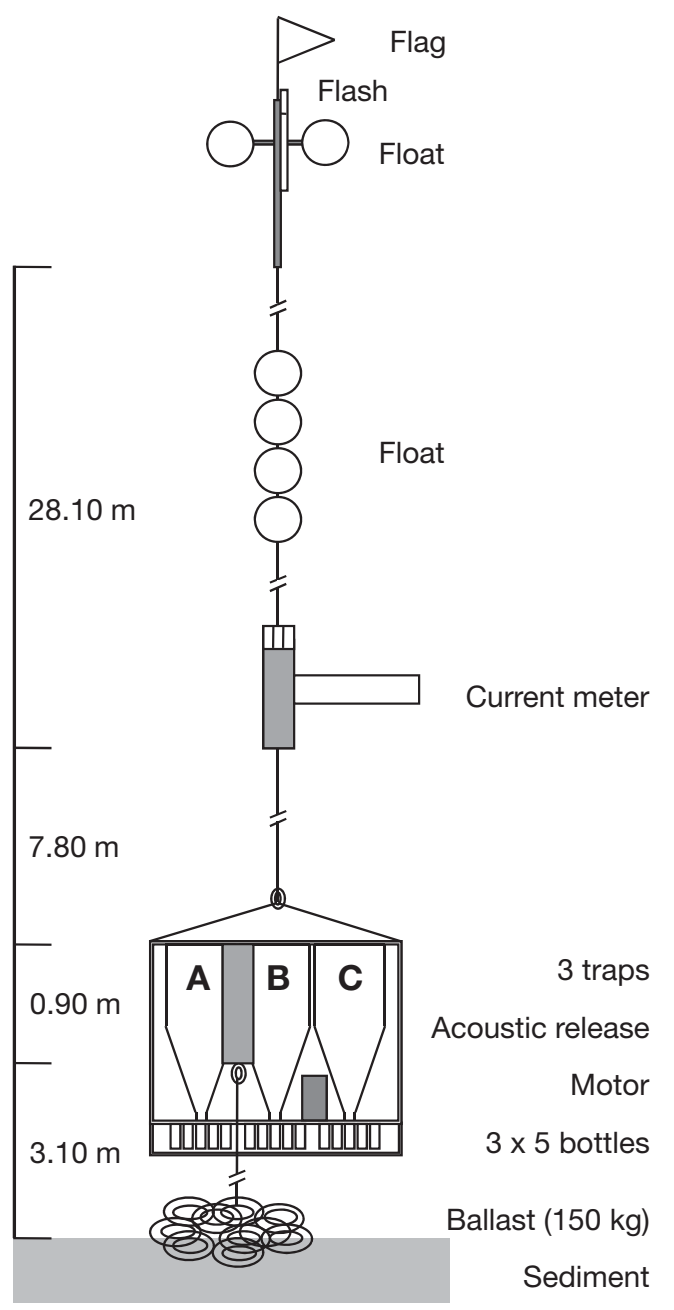

Fig. 2. Schematic representation (not to scale) of the nearbottom mooring deployed on the DYFAMED station between January 1996 and April 1998 included desalting, freeze-drying, estimation of dry mass and analyses of chemical compounds following the procedures described in Khripounoff et al. (1998).

Identification. The benthic copepods from Trap B (Fig. 2) were identified. For counting, specimens were transferred to drops of glycerol on microscope slides and separated to order: Calanoida, Cyclopoida, Harpacticoida. The distinction between Cyclopoida and Poecilostomatoida was not made, following Boxshall \& Halsey (2004). The copepod fauna of the deep Mediterranean is far from completely described, so for the cyclopoid and harpacticoid species encountered, we noted important taxonomic characters and drew a lateral habitus view of an adult female (or male when a female was not available) with the aid of a Nikon Labophot-2 compound microscope equipped with a drawing tube. With this information, we created a key and identified individuals in copepodite stages I through VI to working species. For the harpacticoid families Ectinosomatidae, Miraciidae (formerly Diosaccidae) and Ameiridae, the species-distinguishing characters do not appear until the adult molt. Therefore, the specimens of each of these families were treated as single units. To associate a working species with a described taxon, a specimen was dissected, its appendages mounted and important characters were recorded and illustrated. The keys in Huys et al. (1996), Boxshall \& Halsey (2004) and the primary literature were used to determine the described taxon that came closest to matching the species.

Data and statistics. Because sampling durations were unequal, swimmer abundances were converted to fluxes, i.e. ind. $\mathrm{m}^{-2} \mathrm{~d}^{-1}$. In the graphs of maximum current velocities $\left(V_{\max }\right)$ and swimmer fluxes, the representative point was plotted at the centre of the corresponding collection period.

Relationships between organism fluxes and environmental variables were analyzed using principal component analysis (PCA); environmental variables were 

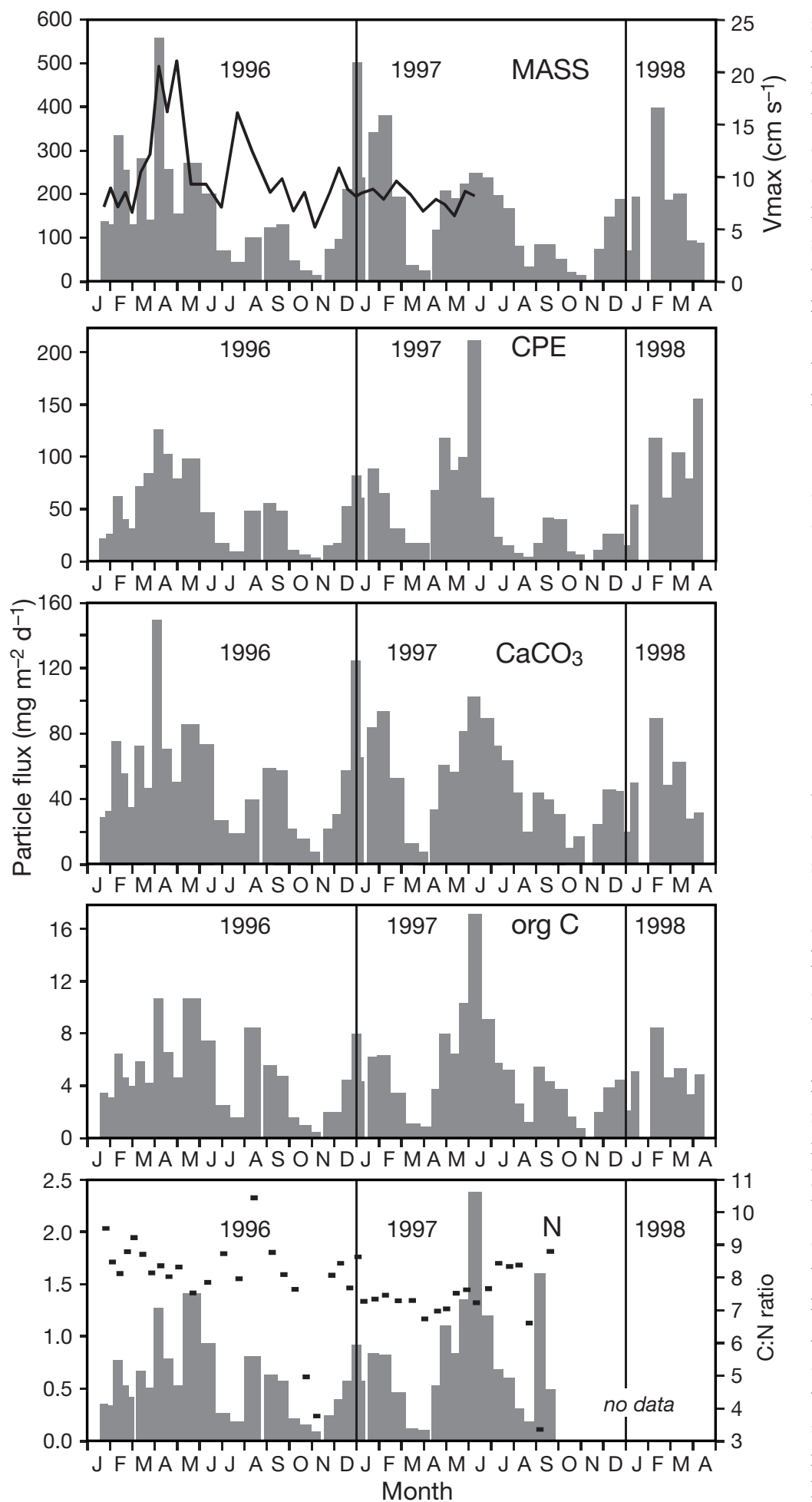

Fig. 3. Particle flux measured $4 \mathrm{~m}$ above bottom between 18 January 1996 and 15 April 1998 (histograms, units on the left): total dry flux (MASS), flux of chloroplastic pigment equivalents (CPE, measured fluorometrically), calcium carbonate $\left(\mathrm{CaCO}_{3}\right)$, organic carbon (org $\mathrm{C}$ ) and nitrogen $(\mathrm{N})$. Black symbols in bottom panel are the corresponding $\mathrm{C}: \mathrm{N}$ ratios (scale on the right). Black curve in the top panel is the maximum current velocity ( $\left.V_{\max }\right)$ recorded $12 \mathrm{~m}$ above bottom during each collection period between 18 January 1996 and 16 June 1997 (units on the right) set as active, while swimmer fluxes were projected as supplementary variables in the resulting factorial space. To compare particulate matter fluxes to fluxes of dominant copepod life-history stages, we used crosscorrelation analyses followed by Spearman rank tests. Each dataset (factorial axis and swimmer fluxes) was treated as a stationary time series, and paired correlations in 14-d increments were computed from 0 to $84 \mathrm{~d}$ (i.e. the lag of the second data set relative to the first data set). Flux data were not transformed. Missing values ( $V_{\max }$ after 16 June 1997, nitrogen fluxes and C:N ratios after 25 September 1997) were replaced by the average value of the corresponding variable. All analyses were performed with TANAGRA (Rakotomalala 2005).

\section{RESULTS}

\section{Environmental variables}

Environmental variables will be described briefly in this section and will only be discussed further from the perspective of the swimmers.

Fig. 3 (top panel) shows the maximum current velocities recorded during each collection period between mid-January 1996 and mid-June 1997. At the DYFAMED station, bottom current speed rarely exceeds $10 \mathrm{~cm} \mathrm{~s}^{-1}$. For example, in 1995, the same mooring measured a mean bottom current speed of $3.70 \mathrm{~cm} \mathrm{~s}^{-1}$ with only one value reaching a maximum of $10.18 \mathrm{~cm} \mathrm{~s}^{-1}$ (A. Khripounoff unpubl. data). In 1996 however, bottom current speed was higher, with an annual mean of $5.28 \mathrm{~cm} \mathrm{~s}^{-1}$. A total of 4 benthic storms (see Aller 1989) with peak velocities between 13 and $21 \mathrm{~cm} \mathrm{~s}^{-1}$ occurred in April, and maximum current speed rose again (16 $\mathrm{cm} \mathrm{s}^{-1}$ ) at the end of July. In 1997 , the incomplete data set (mean current speed $=3.73 \mathrm{~cm} \mathrm{~s}^{-1}$, maximum speed $=9.42 \mathrm{~cm} \mathrm{~s}^{-1}$ ) nevertheless suggests that the bottom hydrodynamic conditions were comparable to those observed in 1995.

Fig. 3 also shows the particle fluxes measured in the samples after removal of the swimmers. There were strong seasonal signals in the input of particles to the bottom, with marked peaks in winter through spring, and lower secondary pulses at the end of 
summer. Mass and calcium carbonate $\left(\mathrm{CaCO}_{3}\right)$ fluxes distributions were comparable, with a maximum value (554.59 and $149.73 \mathrm{mg} \mathrm{m}^{-2} \mathrm{~d}^{-1}$, respectively) recorded in early April 1996 at the onset of the first benthic storm. For all the other fluxes measured, i.e. chloroplastic pigment equivalents (CPE), organic carbon (org C) and nitrogen (N), the maximum input occurred in June $1997(212.45 \mu \mathrm{g}$ $\mathrm{m}^{-2} \mathrm{~d}^{-1}, 17.23$ and $2.38 \mathrm{mg} \mathrm{m}^{-2} \mathrm{~d}^{-1}$, respectively). A second $\mathrm{N}$-flux peak, corresponding to a very low $\mathrm{C}: \mathrm{N}$ ratio (3.36), occurred 3 mo later $\left(1.60 \mathrm{mg} \mathrm{m}^{-2} \mathrm{~d}^{-1}\right)$.

Interannual variability between 1996 and 1997 occurred in the magnitude, timing and duration of the input peaks (Fig. 3); however, concerning the overall annual fluxes it was low. Fig. 4 shows that while the CPE and org $\mathrm{C}$ annual fluxes were equivalent in both years, mass and $\mathrm{CaCO}_{3}$ annual fluxes were slightly higher in 1996, probably reflecting resuspension by strong bottom currents.

\section{Swimmer composition}

A total of 5253 organisms were removed from the 55 collecting bottles, each containing between 18 and 354 swimmers larger than $100 \mu \mathrm{m}$ (Table 1). Copepods (excluding nauplii) largely dominated (Table 2). Nauplii were the second most abundant group and appeared to belong almost exclusively to the harpacticoids. Annelids were essentially larval polychaetes.

Of the 3949 copepods sorted, 19 were damaged and were not considered further. Of the 3930 copepods examined, $4 \%$ were calanoids, $15 \%$ were harpacticoids and $81 \%$ were cyclopoids. Among the non-

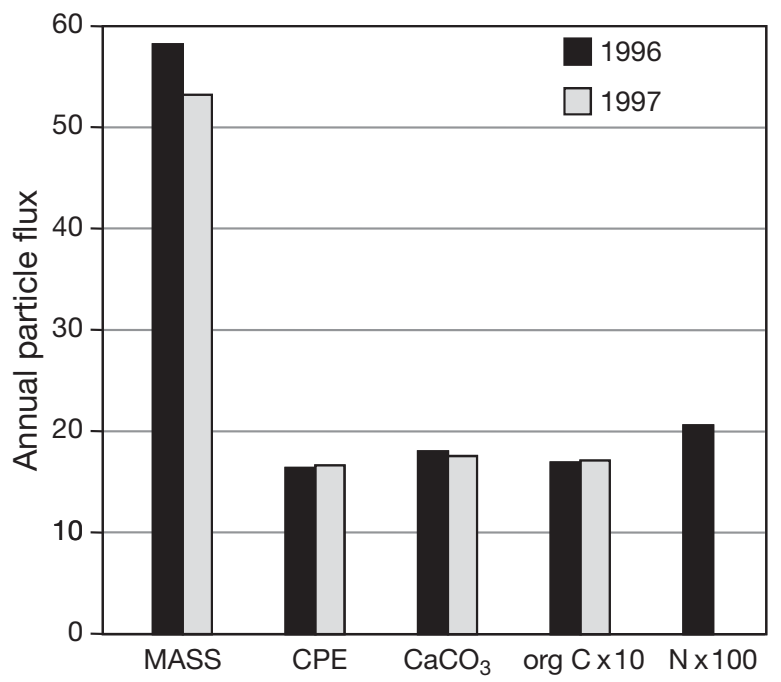

Fig. 4. Annual particle fluxes measured $4 \mathrm{~m}$ above bottom in 1996 and 1997. Units for MASS, $\mathrm{CaCO}_{3}$, org $\mathrm{C}$ and $\mathrm{N}$ flux are $\mathrm{g} \mathrm{m}^{-2} \mathrm{yr}^{-1}$. Units for CPE flux are $\mathrm{mg} \mathrm{m}^{-2} \mathrm{yr}^{-1}$. Values multiplied by 10 for org $\mathrm{C}$ flux, and by 100 for $\mathrm{N}$ flux. $\mathrm{N}$ flux for 1997 not calculated due to missing data calanoid copepods, 25 working species/groups were distinguished, 2 of which were cyclopoids (SP101 and SP102) and 23 harpacticoids (SP1 to SP22, Cer and Unk) (Table 3); 5 taxa were groups of species, i.e. the oncaeids SP102, the ectinosomatids SP5, the miraciids SP1121, the ameirids SP13 and a group of unidentifiable specimens (Unk). All the others were single species, for 6 of which we could not establish the family name; 2 are new species, the cyclopinid Barathricola (SP101) and the huntermanniid Talpina (SP7) (Martínez Arbizu pers. comm.). Most harpacticoid species/ groups were poorly represented (1 to 54 individuals). Among all the copepods listed in Table 3, 2 species were particularly abundant: SP101 represented $90 \%$ of the cyclopoids, and SP1 (the tisbid Tisbe) represented $57 \%$ of the harpacticoids. Juvenile individuals (copepodites) comprised $42 \%$ of both the total cyclopoids and harpacticoids (Table 3 ). However, they were more represented in the oncaeids (SP102) and in Tisbe (SP1) (65 and $62 \%$ of the total individuals, respectively) than in Barathricola (SP101) (39\%). Adult females outnumbered adult males in the cyclopoids (sex ratio $=0.63$ ), while the situation was reversed in harpacticoids (sex ratio $=0.37$ ).

The most remarkable feature of the copepod community structure was the numerical dominance of only 2 benthic copepod species, Barathricola and Tisbe which together represented $\sim 93 \%$ of the benthic copepods and $61 \%$ of the total swimmers. Considering that among the taxa examined only the calanoids and SP102 were planktonic, we can conclude that over $90 \%$ of the swimmers collected were benthic.

\section{Swimmer temporal fluctuations}

Fig. 5A shows the temporal distribution of total swimmer, total copepod and nauplii fluxes. Total swimmer

Table 2. Taxonomic composition, abundance and contribution to total swimmers collected $4 \mathrm{~m}$ above bottom between 18 January 1996 and 15 April 1998 at the DYFAMED station. Others: cumaceans, tanaids, gastropods, sea stars, chaetognaths and appendicularians

\begin{tabular}{|lccc|}
\hline Taxon & Abbreviation & Number & $\%$ \\
\hline Copepods & Cop & 3949 & 75.2 \\
Nauplii & Nau & 608 & 11.6 \\
Annelids & Ann & 409 & 7.8 \\
Nematodes & Nem & 101 & 1.9 \\
Bivalves & Biv & 96 & 1.8 \\
Ostracods & Ost & 29 & 0.6 \\
Isopods & Iso & 20 & 0.4 \\
Amphipods & Amp & 14 & 0.3 \\
Others & Oth & 27 & 0.5 \\
Total & & 5253 & 100 \\
\hline
\end{tabular}


Table 3. General features of the non-calanoid copepod species/groups. Single species are SP101 for cyclopoids, SP1 to 4, SP6 to 10, SP12, SP14 to 20, SP22 and Cer for harpacticoids; groups are SP102 for cyclopoids, SP5, SP1121, SP13 and Unk for harpacticoids. Sex ratio was calculated as the proportion of females to total adults. The immature copepodite stages are grouped under juveniles

\begin{tabular}{|c|c|c|c|c|c|c|c|}
\hline \multirow{2}{*}{ Family } & \multirow{2}{*}{ Genus } & \multirow{2}{*}{$\begin{array}{l}\text { Working species } \\
\text { or group }\end{array}$} & \multirow{2}{*}{$\overline{\text { Females }}$} & \multicolumn{2}{|c|}{ Number } & \multirow[b]{2}{*}{ Total } & \multirow{2}{*}{$\begin{array}{l}\text { Sex } \\
\text { ratio }\end{array}$} \\
\hline & & & & Males & Juveniles & & \\
\hline \multicolumn{8}{|l|}{ Cyclopoida } \\
\hline Cyclopinidae & Barathricola & SP101 & 1095 & 633 & 1120 & 2848 & 0.63 \\
\hline Oncaeidae & Oncaea & SP102 & 70 & 44 & 211 & 325 & 0.61 \\
\hline Total & & & 1165 & 677 & 1331 & 3173 & 0.63 \\
\hline \multicolumn{8}{|l|}{ Harpacticoida } \\
\hline Tisbidae & Tisbe & SP1 & 55 & 75 & 210 & 340 & 0.42 \\
\hline$?$ & & SP2 & 9 & 18 & 1 & 28 & 0.33 \\
\hline ? & & SP3 & 2 & 3 & 1 & 6 & 0.40 \\
\hline ? & & SP4 & 3 & 1 & 5 & 9 & 0.75 \\
\hline Ectinosomatidae & & SP5 & 20 & 26 & 8 & 54 & 0.43 \\
\hline Huntermanniidae & Talpina & SP7 & 6 & 7 & 0 & 13 & 0.46 \\
\hline Canthocamptidae & & SP8 & 4 & 1 & 1 & 6 & 0.80 \\
\hline Canthocamptidae & & SP9 & 1 & 5 & 1 & 7 & 0.17 \\
\hline Canthocamptidae & & SP10 & 4 & 6 & 1 & 11 & 0.40 \\
\hline Miraciidae & & SP1121 & 2 & 1 & 0 & 3 & 0.67 \\
\hline Ameiridae & & SP13 & 2 & 3 & 0 & 5 & 0.40 \\
\hline Argestidae & & SP6 & 5 & 0 & 1 & 6 & 1.00 \\
\hline Argestidae & Mesocletodes & SP12 & 3 & 0 & 0 & 3 & 1.00 \\
\hline Argestidae & Stylicletodes & SP14 & 1 & 0 & 0 & 1 & 1.00 \\
\hline Argestidae & & SP15 & 2 & 2 & 0 & 4 & 0.50 \\
\hline Argestidae & & SP16 & 2 & 0 & 1 & 3 & 1.00 \\
\hline Argestidae & & SP17 & 1 & 2 & 1 & 4 & 0.33 \\
\hline Argestidae & & SP19 & 1 & 0 & 0 & 1 & 1.00 \\
\hline Argestidae & Mesocletodes & SP22 & 0 & 18 & 0 & 18 & 0.00 \\
\hline$?$ & & SP18 & 1 & 1 & 0 & 2 & 0.50 \\
\hline$?$ & & SP20 & 1 & 1 & 0 & 2 & 0.50 \\
\hline Cerviniidae & Pontostatiotes & Cer & 0 & 3 & 10 & 13 & 0.00 \\
\hline$?$ & & Unk & 0 & 43 & 11 & 54 & 0.00 \\
\hline Total & & & 125 & 216 & 252 & 593 & 0.37 \\
\hline
\end{tabular}

fluxes varied greatly over time (26 to 361 ind. $\mathrm{m}^{-2} \mathrm{~d}^{-1}$ ). Their distribution generally matched that of total copepods. Major copepod flux peaks occurred in early June 1996, early July 1997 and late September 1997. Nauplii fluxes were more or less out of phase with those of copepods, with one major peak in late October 1996. Nauplii were not always present in the samples, nor were annelids, bivalves or nematodes (Fig. 5B). Major annelid and bivalve flux peaks were concomitant in late November 1996, early July 1997 and early September 1997. Bivalves also peaked in early April 1996, but annelids did not. Mean nematode flux was generally low $\left(<2\right.$ ind. $\left.\mathrm{m}^{-2} \mathrm{~d}^{-1}\right)$, but the occurrence of these organisms increased in early April and May 1996 (8 ind. $\mathrm{m}^{-2} \mathrm{~d}^{-1}$ ). The fluxes of the 3 copepod orders, cyclopoids, harpacticoids and calanoids, followed different patterns (Fig. 5C). The cyclopoid flux pattern roughly followed that of total copepods, matching the same 3 main peaks. Harpacticoid fluxes were low in 1996 with a peak in late November. In 1997, the first flux peak in early July occurred at the same time as that of the cyclopoids, but the second occurred earlier in September. Calanoid fluxes were low and never exceeded 10 ind. $\mathrm{m}^{-2} \mathrm{~d}^{-1}$. Fig. 5D shows the fluxes of the 2 dominant copepod species, SP101 and SP1. Due to the outstanding dominance of SP101 within the cyclopoids, its temporal flux pattern coincided with that of the order. For SP1, only the flux peak in early July 1997 was concomitant with that of the harpacticoids. Other main peaks occurred either 1 mo earlier (in late October 1996) or later in the month (in September 1997) than those of the order.

Temporal variations in swimmer fluxes were high within years as well as between years. Fig. 6 shows that the mean annual flux of copepods and annelids in 1997 was more than twice that measured in 1996. The trend was reversed for nematodes, which were slightly more abundant in the 1996 samples. Nauplii, bivalve and calanoid mean annual fluxes were roughly the same in both years. In contrast, those of the 2 dominant copepod species differed greatly. They increased by a factor of 3 for SP101 and by a factor of more than 4 for SP1. Among the non-calanoid copepods, species/ groups composition also varied between 1996 and 

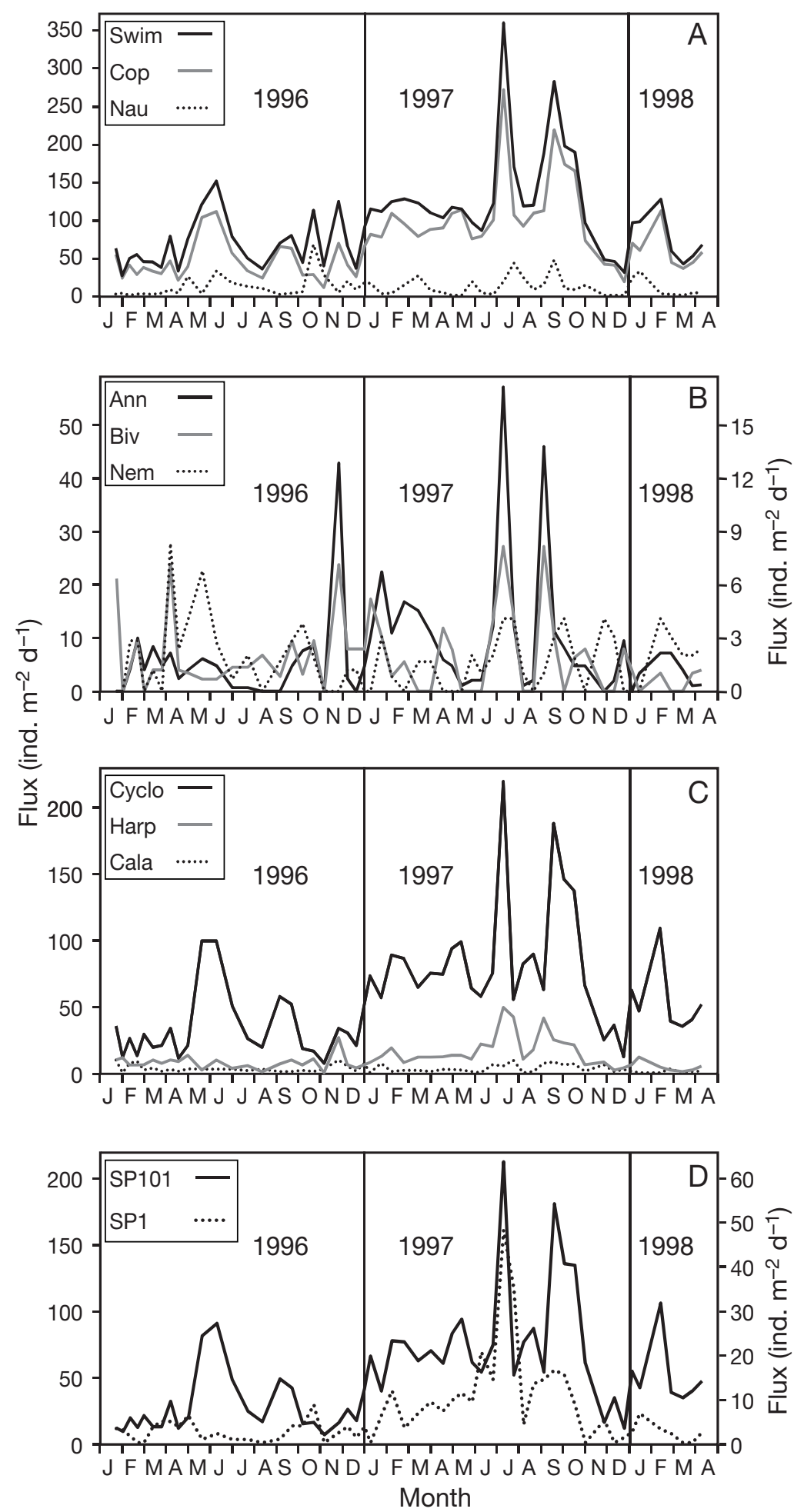

Fig. 5. Swimmer flux measured $4 \mathrm{~m}$ above bottom between 18 January 1996 and 15 April 1998. (A) total swimmers (Swim), total copepods (Cop) and nauplii (Nau); (B) annelids (Ann) (units on left), bivalves (Biv) and nematodes (Nem) (units on right); (C) cyclopoids (Cyclo), harpacticoids (Harp) and calanoids (Cala); (D) flux of the 2 dominant copepod species, the cyclopoid Barathricola (SP101) and the harpacticoid Tisbe (SP1) (units on right)
1997. Of the 25 species/groups distinguished (Table 3), 3 (SP4, SP6, SP20) only occurred during the first year of the study, and 6 (SP1121, SP12, SP14, SP15, SP18, SP19) only during the second year. Since more harpacticoid species/ groups were present in 1997, harpacticoid species diversity was higher in 1997 than in 1996. Moreover, while only the oncaeids (SP102) were equally represented in both years, out of the 15 remaining species/groups, 3 (SP2, SP3, SP9) were more abundant in 1996 and 12 were more abundant in 1997.

\section{Swimmers and environmental variables}

To understand the swimmer temporal variations, we ran PCA in which active variables were those of the environment. The first 3 factorial axes explained $86.28 \%$ of environmental variability (Table 4). Axis 1 (57.35\%) was strongly correlated to the different particle fluxes, and to $V_{\max }$ to a much lesser extent, in the negative values. Axis $2(17.63 \%)$ was strongly correlated to C:N ratios and $V_{\max }$ in the negative values, and to $\mathrm{N}$-fluxes in the positive values. Axis $3(11.30 \%)$ was significantly correlated to $V_{\max }$ in the positive values, and to C:N ratios in the negative values. Axis 1 can thus be interpreted as representing 'particle flux' increasing in the negative values, Axis 2 'current velocities that decrease particle quality' increasing in the negative values and Axis 3 'current velocities that increase particle quality' increasing in the positive values. Because strong near-bottom flow is likely to erode and resuspend refractory sediment, it will increase both near-bottom particle fluxes (Axis 1) and the $\mathrm{C}: \mathrm{N}$ ratio of trapped particles by incorporating 'old' particles into the 'fresh' influx (Axis 2) (see Lampitt 1985). On the other hand, current velocities in excess of $7 \mathrm{~cm} \mathrm{~s}^{-1}$ are sufficient to elicit resuspension of loose, freshly deposited, high quality aggregates (rebound flux) (see Lampitt et al. 2001), thereby decreasing the $\mathrm{C}: \mathrm{N}$ ratio of trapped particles (Axis 3). Consequently, Axis 2 would correspond to 'erosion current' and Axis 3 to 'rebound current'.

Fluxes of 33 swimmer taxa/groups/species (i.e. 8 higher taxa/groups, calanoids and 24 out of the 25 working species/groups) were projected as supplementary variables in the planes defined by the first 3 factorial axes (Fig. 7). Highest dispersion of swimmer fluxes occurred along Axis 2. Of the 99 resulting correlation 


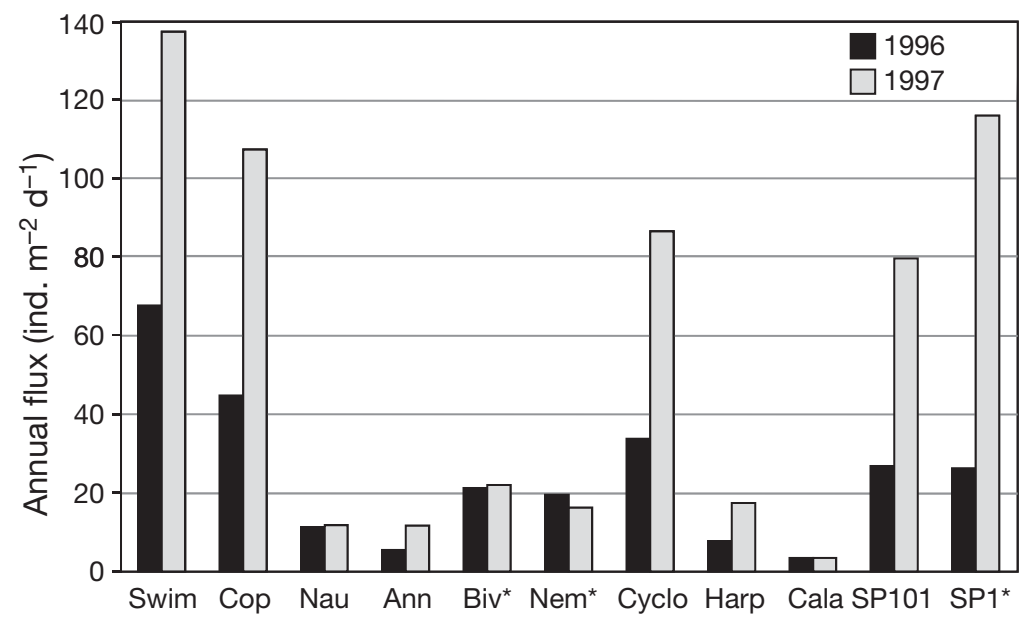

Fig. 6. Mean annual swimmer flux (ind. $\mathrm{m}^{-2} \mathrm{~d}^{-1}$ ) measured $4 \mathrm{~m}$ above bottom in 1996 and 1997. Total swimmers (Swim), total copepods (Cop), nauplii (Nau), annelids (Ann), bivalves (Biv), nematodes (Nem), total cyclopoids (Cyclo), harpacticoids (Harp), calanoids (Cala), Barathricola (SP101) and Tisbe (SP1). ${ }^{*}$ values multiplied by 10

coefficients, 22 (involving 14 taxa/groups/species) were significant ( $\mathrm{p} \leq 0.05)$. Nematode (Nem) and SP6 fluxes increased with increasing particle flux $(\mathrm{r}=-0.36$ and -0.30 , respectively). They also increased with increasing erosion current ( $\mathrm{r}=-0.23$ and -0.24 , respectively), as did SP2 and SP4 fluxes $(r=-0.22$ and -0.43 , respectively). This indicates that these benthic taxa/species were passively resuspended by strong bottom flow. Nematode and SP4 fluxes, along with those of nauplii, ostracods, isopods, 'others', SP7, SP18 and SP20 increased with increasing rebound current $(\mathrm{r}=0.27$, $0.32,0.22,0.24,0.24,0.37,0.26,0.23$ and 0.23 , respectively), indicating that they entered the water column on rebound aggregates. The fluxes of nauplii, ostracods and SP5 increased when particle flux was low ( $\mathrm{r}=$ $0.28,0.30$ and 0.25 , respectively), probably because these organisms entered the water column actively in response to food shortage. The fluxes of ostracods, SP10 and SP18 increased when erosion current decreased ( $r=0.26,0.29$ and 0.25 , respectively), revealing avoidance of resuspension by strong bottom flow. Only SP102 fluxes were negatively correlated to rebound current $(\mathrm{r}=-0.34)$.

Fig. 8 shows the temporal patterns of environmental conditions summarized by the observation coordinates on the 3 factorial axes (top) along with those of SP101 and SP1 fluxes (bottom). It suggests that the temporal fluctuations in these 2 species' fluxes involved lagged reactions. Because PCA Axis 1 includes the food for deep-living organisms, any improved correlation in the negative values of this axis after lagging the swimmer fluxes by 1 and 2 collection periods would reveal a population growth response. This was indeed observed for SP101 and SP1 fluxes $(r=-0.22$ and -0.38 , respectively), and for annelid and SP4 fluxes ( $\mathrm{r}=-0.24$ and -0.27 , respectively) after $28 \mathrm{~d}$. Concerning the former, a cross-correlation analysis (Fig. 9) confirmed a growth response. It showed that a peak of SP101 juveniles within $14 \mathrm{~d}$ following the food influx led to a peak of adults within the next $14 \mathrm{~d}$, and that a peak of SP1 juveniles between 14 and $28 \mathrm{~d}$ led to a peak of adults between 28 and $42 \mathrm{~d}$. Moreover, the 14-d lagged PCA displayed effects that persisted in time. The correlation coefficients of SP5, SP17 and SP22 fluxes with Axis 1 in the positive values (low particle flux) were improved $(r=0.33,0.25$ and 0.26, respectively), suggesting that aggravated food shortage enhanced the active entry into the water column of these groups/species. The correlation coefficient of some species fluxes with increasing erosion current (Axis 2 in the negative values) were either improved (SP3, $\mathrm{r}=-0.29$; SP6, $\mathrm{r}=$ -0.41 ) or remained significant (SP4, $r=-0.34$ ), indicating that once eroded by strong bottom current, these species accumulated in the water column and did not re-enter the benthos within the following $2 \mathrm{wk}$. The correlation coefficients of nematodes, SP17 and SP18 fluxes with increasing rebound current (Axis 3 in the positive values) were also improved ( $\mathrm{r}=0.30,0.29$ and 0.35, respectively), indicating that these organisms accumulated in the water column on rebound aggregates. Finally, increased erosion current (Axis 2 in the negative values) led to a significant decrease in the fluxes of annelids, bivalves, calanoids, SP101, SP1, SP8, SP10, SP17, SP18 and SP22 $(r=0.33,0.25,0.34$, $0.34,0.26,0.24,0.23,0.40,0.34$ and 0.41 , respectively) within the following $2 \mathrm{wk}$. This suggests that the organisms either avoided the water column (active behavior) or that erosion had a lethal effect on them (passive). Table 5 summarizes the different responses revealed by the statistical analyses for 23 of the 33 swimmer taxa examined.

Table 4. Correlation coefficients between active variables and principal components analysis factorial axes. Bold: $p<0.05$. MASS: total dry flux; CPE: chloroplastic pigment equivalents; Org C: organic carbon; $V_{\max }$ : maximum current velocity

\begin{tabular}{|lccc|}
\hline Active variables & Axis 1 & Axis 2 & Axis 3 \\
\hline MASS & $\mathbf{- 0 . 8 5}$ & -0.14 & -0.15 \\
$\mathrm{CPE}$ & $\mathbf{- 0 . 8 4}$ & +0.12 & +0.05 \\
$\mathrm{CaCO}_{3}$ & $\mathbf{- 0 . 9 4}$ & -0.07 & -0.07 \\
$\mathrm{Org} \mathrm{C}_{\mathrm{N}}$ & $\mathbf{- 0 . 9 5}$ & +0.13 & -0.06 \\
$\mathrm{C}: \mathrm{N}$ & $\mathbf{- 0 . 8 3}$ & $\mathbf{+ 0 . 3 6}$ & +0.12 \\
$V_{\text {max }}$ & -0.20 & $\mathbf{- 0 . 8 0}$ & $\mathbf{- 0 . 4 8}$ \\
\end{tabular}



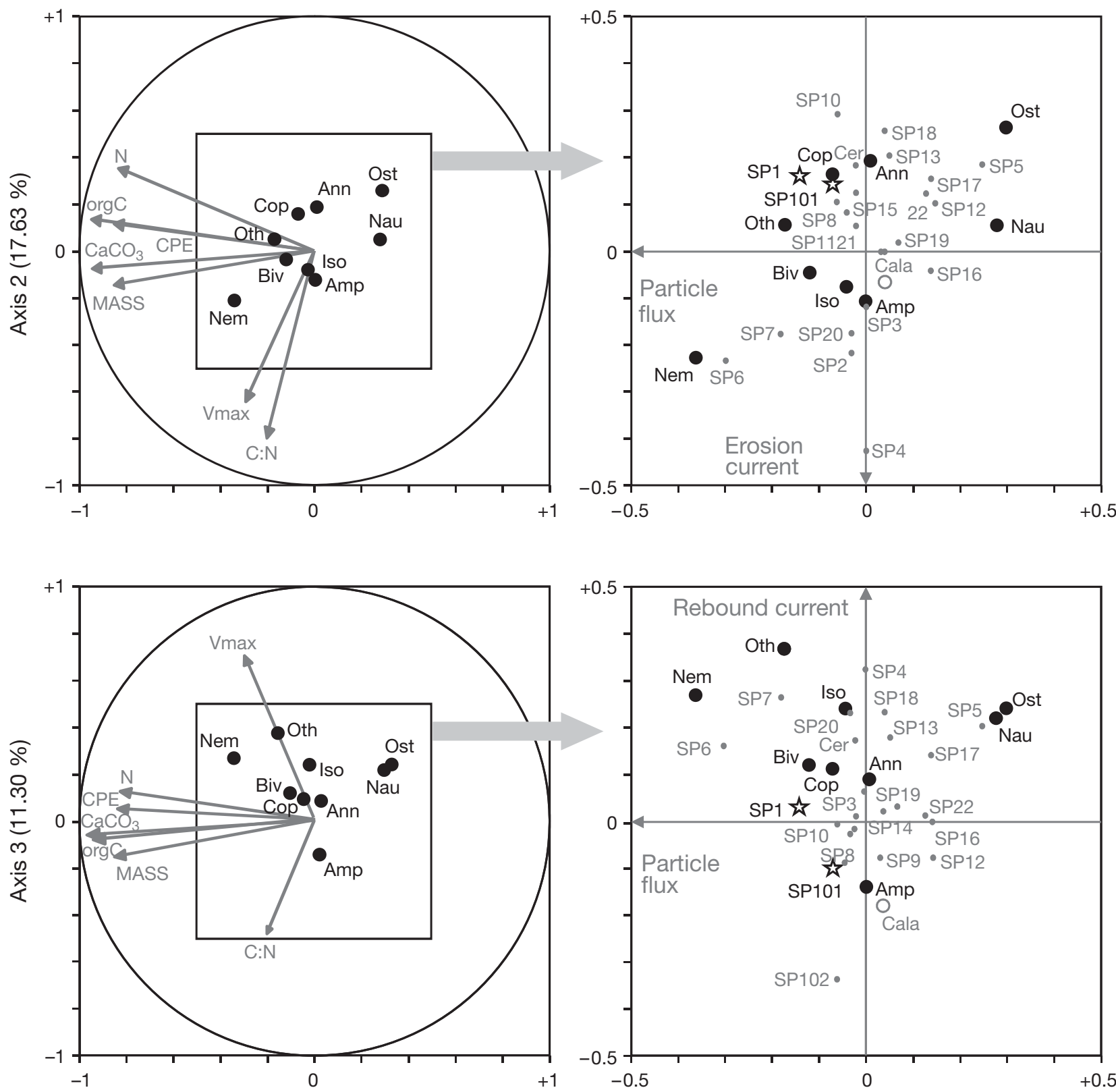

Axis $1(57.35 \%)$

Fig. 7. Principal component analysis correlation circles showing the distribution of the different swimmer taxa projected as supplementary variables (dots and stars indicate tips of vectors) in the planes defined by the first 3 factorial axes explaining $86.28 \%$ of environmental variability. Left panels display only major taxa (large dots). Right panels are close-ups that display all taxa except total cyclopoids, harpacticoids and unidentified specimens (small grey dots are species/groups, stars are the 2 dominant species). In the close-up of Axes 1 and 2 (top), labels of SP9, SP14 (near the centre) and SP102 (near SP101) were omitted. Likewise for SP2, SP15 and SP1121 (near the centre) in the close-up of Axes 1 and 3 (bottom). MASS: total dry flux; CPE: chloroplastic pigment equivalents;

Org C: organic carbon; $V_{\max }$ : maximum current velocity. See Tables $2 \& 3$ for other abbreviations

\section{DISCUSSION}

\section{General considerations}

In bathyal and abyssal habitats, the benthopelagic community or hyperbenthos (see Mees \& Jones 1997) has typically been sampled with specially designed plankton nets, benthic trawls and nets or pumps on submersibles. These techniques have been used to collect samples for species descriptions, community structure (e.g. Wishner 1980) and food-web analyses (e.g. Bühring \& Christiansen 2001), as well as metabolism measurements (e.g. Smith et al. 1987). They have led to the general agreement that the near-bottom plank- 

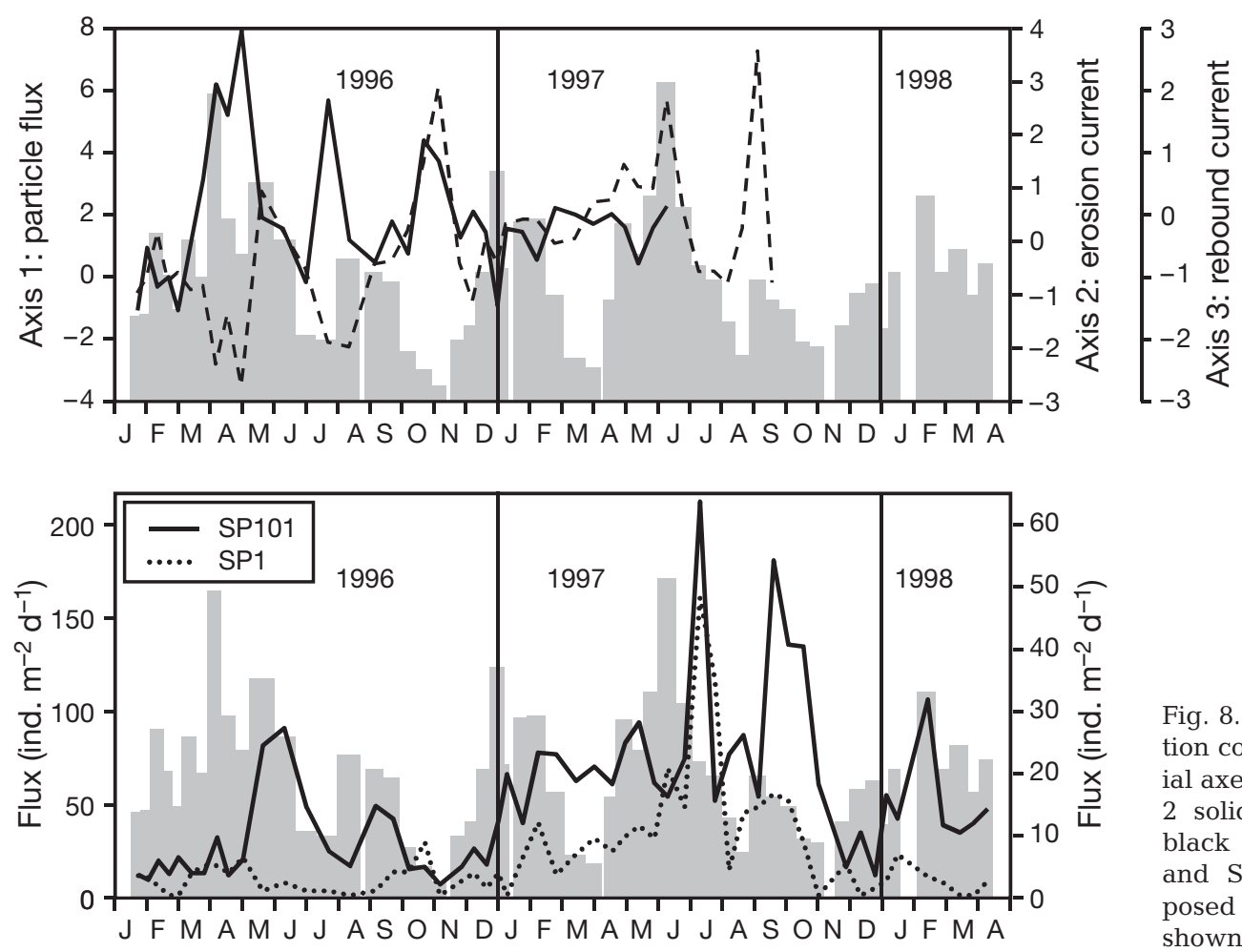

Fig. 8. Temporal pattern of observation coordinates on the 3 first factorial axes (top) (Axis 1 histogram, Axis 2 solid black line, Axis 3 dashed black line; arbitrary units). SP101 and SP1 fluxes (bottom) superimposed on pattern of Axis 1 (units not shown) (SP1 flux units on the right)

ton of most deep-sea environments is numerically dominated by copepods, which contribute between 50 and $>90 \%$ of the benthopelagic community. The present study in the deep NW Mediterranean, with a different sampler (i.e. sediment traps) also showed a high dominance of copepods, which comprised on average $75 \%$ of the organisms collected. While previous investigations essentially sampled planktonic organisms, the great majority $(90 \%)$ of the organisms collected in the present study were benthic. This discrepancy could be caused by the large mesh sizes used in traditional benthopelagic studies $(\geq 183 \mu \mathrm{m})$ and/or by the

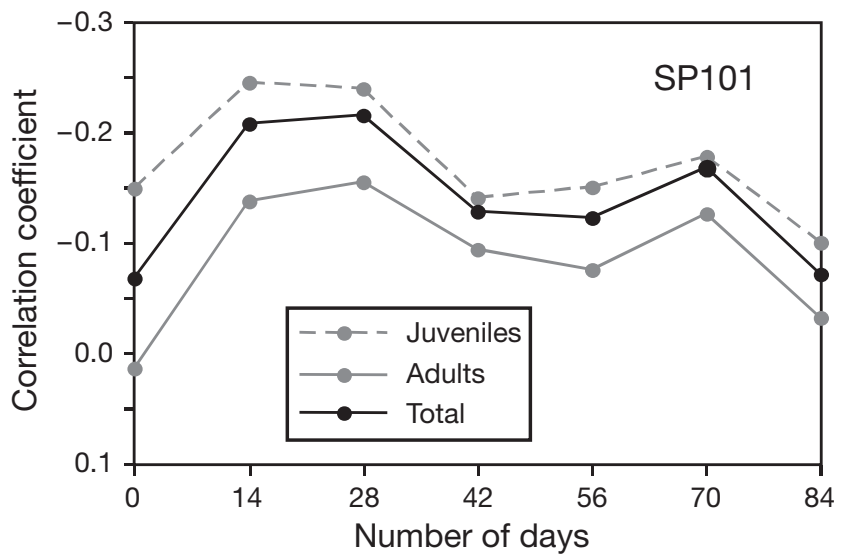

different heights above the bottom sampled (generally $\geq 10$ mab, but see Smith et al. 1987). The differences could also result from the gear itself or from specificities of the deep Mediterranean. Note that virtually none of the traditional benthopelagic studies sampled the same location more than once, probably because of logistic constraints. Sediment traps currently used to measure oceanic particle fluxes, inevitably collect swimmers (see Karl \& Knauer 1989). While these are usually removed (and discarded) because they artificially augment the trap contents, one may be missing a chance to obtain time-series samples of an organism of

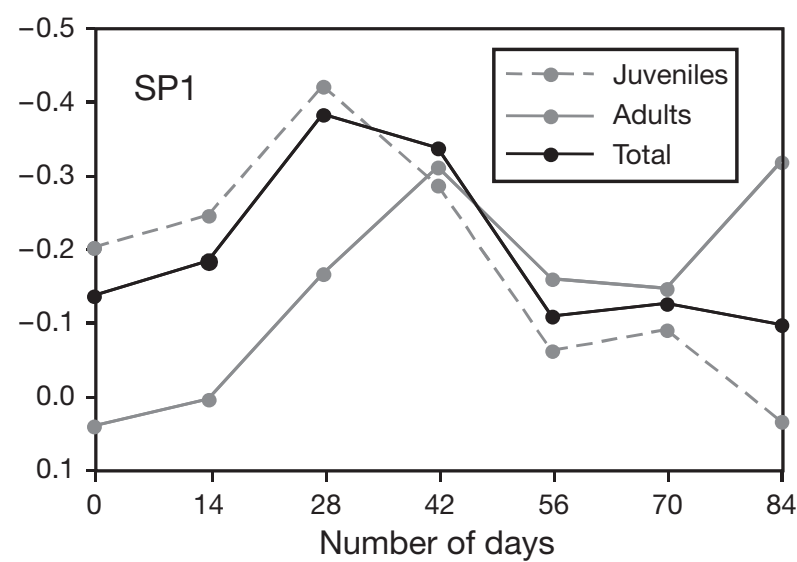

Fig. 9. Correlations between principal component analysis Axis 1 and fluxes of the different life history stages of SP101 and SP1 lagged in 14-d increments 


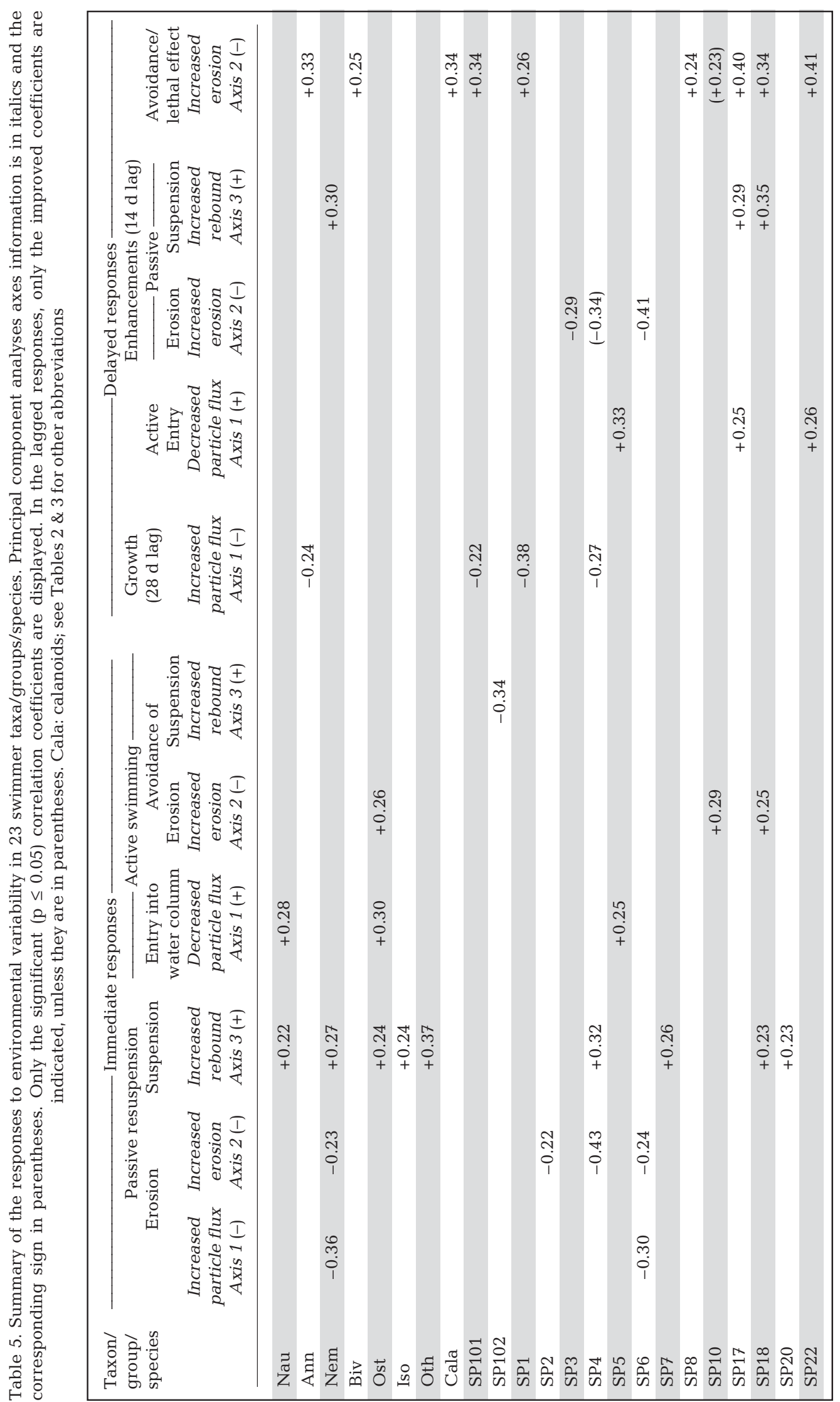


interest. On a few occasions, sediment traps have been used to study seasonal variations of mid-water zooplankton in 'hostile' environments such as the polar regions (Hargrave et al. 1989, Seiler \& Brandt 1997, Willis et al. 2006). Most studies have focused on the analysis of the 'contaminating' effect of swimmers on particle flux organic content (e.g. Steinberg et al. 1998). A few studies have used sediment traps to investigate the occurrence of meiofaunal taxa in the water column of shallow coastal settings (e.g. Hagerman \& Rieger 1981, Shanks \& Edmondson 1990). None have previously been conducted in the BBL of the deep sea.

The BBL, i.e. the layer of water typically tens of metres thick above the seabed, is a highly variable environment. According to Lampitt (1985) and Lampitt et al. (2000, 2001), material collected in near-bottom sediment traps gives a measure of apparent flux as opposed to the primary flux measured higher in the water column. Traps set within the BBL collect material that is a mixture of particles from 3 sources: (1) particles that have settled directly from the overlying water column (primary flux), (2) mineral particles that have been eroded from the sediment (erosion flux) and (3) freshly deposited particles that have been resuspended from the local seabed (i.e. rebound flux). The contribution of the latter 2 to the former depends on bottom current speed, which can be highly variable, as shown in the present study. Gardner \& Richardson (1992) reported that burst events lift particles off the seafloor and resuspension occurs primarily when bottom current speed exceeds a critical value, i.e. $\sim 11$ to $12 \mathrm{~cm} \mathrm{~s}^{-1}$ for sediment erosion and $\sim 7 \mathrm{~cm} \mathrm{~s}^{-1}$ (at $1 \mathrm{mab}$, Lampitt 1985) for resuspension of newly arrived detrital aggregates. These authors suspected that quite subtle changes in the near-bottom current regime would have substantial effects on the structure of both benthic and benthopelagic communities.

The metazoan meiobenthic community at the DYFAMED station is typical of deep-sea muddy bottoms (see Giere 2009), with densities ranging from 133 to 770 ind. per $10 \mathrm{~cm}^{2}$ (Guidi-Guilvard 2002). Nematodes dominate $(88.8 \%)$ and are followed by copepods (harpacticoids and cyclopoids) along with their nauplii $(9.6 \%)$ and annelids $(1.1 \%)$. Other groups are rare $(<0.6 \%)$. The vertical distribution of organisms in the sediment column is also typical of the deep sea. About $94 \%$ of the ostracods, $80 \%$ of the copepods and the nauplii, $52 \%$ of the annelids and $40 \%$ of the nematodes occur in the top $1 \mathrm{~cm}$ of sediment (L. D. GuidiGuilvard unpubl. data), the layer most exposed to physical reworking. Thistle et al. (1991) reported that during benthic storms, near-bottom current speeds similar to those measured at the DYFAMED site in April $1996\left(\geq 20 \mathrm{~cm} \mathrm{~s}^{-1}\right)$ could erode as much as $1 \mathrm{~cm}$ of sediment. So, given the hydrodynamic context, it is not surprising that the benthopelagic community was largely composed of the benthic taxa that tend to concentrate near the sediment surface.

\section{Organism responses to environmental variability}

The behaviour and reactions of deep-sea invertebrates to their environment are poorly known. The interpretation of our results is therefore partly based on what has previously been reported for their counterparts in shallow-water and laboratory studies. We found that the organisms collected 4 mab in the deep NW Mediterranean had both immediate and delayed responses to environmental variability (Table 5). These responses involved both passive and active behavioural reactions, as well as population growth.

Nematodes are typically weakly or non-swimming organisms (e.g. Shanks \& Edmondson 1990). In the present study, they were eroded by strong bottom currents. Passive erosion of nematodes has previously been reported from both shallow-water (e.g. review by Palmer 1988, Guidi-Guilvard \& Buscail 1995) and deep-sea (e.g. Aller 1989) environments. However, after having been eroded, the nematodes did not accumulate in the water column, which indicates rapid settlement. Hagerman \& Rieger (1981) reported that nematodes had a particularly high settling velocity, probably because they cling to resuspended mineral particles. We found that nematodes also entered the water column after having colonized rebound aggregates, and in this case, did accumulate in the water column. Colonization of fresh phytodetrital aggregates by nematodes was observed on top of sediment cores from the deep NE Atlantic by Thiel et al. (1989), and Shanks \& Edmondson (1990) noted that nematodes collected by sediment traps set $\sim 12$ mab in a shallow coastal bay were strongly associated with marine snow. According to these authors, marine snow is a sediment-like habitat suspended in the water column, in which nematodes reside (Shanks \& Walters 1997). Despite their high abundance in the sediment, nematode fluxes were comparatively low at 4 mab (maximum of 8 ind. $\mathrm{m}^{-2} \mathrm{~d}^{-1}$ ). This value nevertheless is similar to that reported by Hagerman \& Rieger (1981) from 1.5 mab in the shallow subtidal (i.e. $10 \mathrm{~m}^{-2} \mathrm{~d}^{-1}$ ). Among the numerous nematode species present in deep-sea sediments, probably only a few feed on fresh phytodetritus (see Iken et al. 2001), because most nematodes are linked to a short detrital or bacterial-based food chain within the sediment (Giere 2009). Moreover, they can avoid physical disturbance by moving deeper (e.g. Palmer 1988, Galéron et al. 2001).

Three harpacticoid species (SP2, SP4 and SP6) were also eroded by strong bottom currents. In contrast to 
the nematodes that rapidly settled, SP4 and SP6 accumulated in the water column in the following weeks, as did SP3. All 4 harpacticoid species were either more abundant in 1996 than in 1997 (SP2 and SP3) or only present in 1996 (SP4 and SP6) when benthic storms occurred. Among these harpacticoids, only SP4 was found to colonize rebound aggregates, along with SP7, SP18 and SP20. The huntermanniid Talpina (SP7) has been observed in the sub-surface layers of sediment cores at the DYFAMED station (L. D. Guidi-Guilvard pers. obs.). Although its morphology shows strong adaptations for burrowing, our results suggest that it moves upwards in the sediment to feed on freshly deposited detritus. Our analyses show that only a few harpacticoid species found in the water column were associated with rebound aggregates. Likewise, Shanks \& Edmondson (1990) reported that only $25 \%$ of the vertical flux of harpacticoids was due to individuals on marine snow. Most harpacticoids in the water column only 'visit' aggregates and actively swim away (Shanks \& Walters 1997). In the present study, other invertebrates were found to colonize rebound aggregates, i.e. isopods, tanaids, gastropods and sea stars (the 3 latter were included in 'others'). Isopods (in Gage \& Tyler 1991) and tanaids (in Higgins \& Thiel 1988), which are detritivores, probably feed on freshly deposited aggregates, and phytodetritus was found in the gut of deepsea asteroids (Thiel et al. 1989).

Freshly deposited aggregates were colonized by cumaceans (included in 'others'), ostracods and nauplii that have good swimming abilities. The 2 latter groups, along with SP5 (ectinosomatids) were also more abundant in the water column when particle flux (food for the benthos) was low. In coastal habitats, many benthic taxa that are good swimmers, e.g. amphipods, ostracods, polychaetes (Mees \& Jones, 1997) and harpacticoid species (e.g. Bell et al. 1988) make excursions into the water column (emergence). Ectinosomatids are good swimmers, and within this harpacticoid family, many species have been identified as emergers, both in shallow water (e.g. Thistle 2003) and in the deep-sea (Thistle et al. 2007). In the present study, emergence of ostracods, nauplii and SP5 was probably a response to a local decline in food, a reason often invoked to explain harpacticoid emergence (e.g. Thistle et al. 2007). When low food conditions persisted, this response was enhanced for SP5, as well as for SP17 and SP22.

The 2 dominant copepod species, SP1 (Tisbe) and SP101 (Barathricola), also emerged. Both were present in trap samples and in sediment cores (L. D. GuidiGuilvard pers. obs.). Following Thistle (2003) and Thistle \& Sedlacek (2004), SP1 has the morphology of an emerger. We are not aware of equivalent rules for benthic cyclopoids, but the genus Barathricola is known to lead an epibenthic lifestyle (Boxshall \& Halsey 2004).
These 2 species exhibited a clear population growth in response to food pulses, but SP101 responded faster than SP1. Development time found in the present study for SP1 is within the range of those reported for Tisbe species reared in the laboratory at equivalent temperatures (Hicks \& Coull 1983). Such a lag response, although strongly expected in deep-sea benthic ecology studies, had never been shown before for meiobenthic copepods (review by Gooday 2002, Kalogeropoulou in press). Our statistical analyses furthermore showed that fluxes of annelids (essentially larval polychaetes) and SP4 also increased within the month following a food pulse. Similarly, Vanreusel et al. (2001) described a mass recruitment of opheliid polychaete juveniles in response to a phytodetrital input in the surface sediment of the deep NE Atlantic. In the present study, the increases in abundance were found in the water column, but they most certainly reflected those that were taking place in the benthos. At least for the 3 copepod species, the individuals could have emerged as a result of overcrowding, another reason often invoked in shallow-water studies to explain harpacticoid emergence. Walters (1991) observed that Tisbe furcata exhibited increased emergence frequency with increased harpacticoid density in the surface sediment. Reproductive activity has also been suggested as a possible explanation for emergence (e.g. Bell et al. 1988). In our trap samples, males of SP1 outnumbered females, which is in agreement with observations on shallow water harpacticoids. Immature individuals were moreover very abundant (copepodites accounted for $62 \%$ of the SP1 population). Because in harpacticoids, adult males mate with subadult females (Hicks \& Coull 1983), the dominance of these 2 stages suggests that they were mating in the water column. However, from a study conducted on a shelf site, Thistle (2003) concluded that harpacticoids do not emerge primarily to find mates. Emergence behaviour would favour dispersal. The individuals collected at a site, especially high above the bottom like in the present study, do not originate from the local seabed. They come from some distance away from where they were advected in. As suggested by Bell et al. (1989), the co-occurrence of males and potential mates (copepodites) in the water column may be a strategy for re-establishment of a new population when the fauna actively re-enter the benthos on new grounds.

Concerning benthic cyclopoids, very little information is available in the literature. Most ecological studies are limited to planktonic species (e.g. Turner 1986, Uye \& Sano 1998). The population of SP101 in our samples was dominated by females. This is in agreement with what is reported for planktonic cyclopoids. However, its behaviour and responses to environmental variability were closer to those of the harpacticoid SP1 
than to those of SP102, a group of holoplanktonic cyclopoids. In the present study, SP102 was the only group that avoided rebound aggregates. Shanks \& Edmondson (1990) also noted that cyclopoid copepods were weakly associated with marine snow. Although oncaeids have been observed feeding on these structures (e.g. Lampitt et al. 1993), they can also be carnivores (e.g. Turner 1986).

Our statistical analyses showed that ostracods, the canthocamptid SP10 and SP18 avoided resuspension by strong bottom flows. Moreover, the fluxes of the 2 latter species, along with those of 2 argestids (SP17 and SP22), another canthocamptid (SP8), SP1, SP101, calanoids, bivalves and annelids decreased in the following weeks. Many benthic organisms are capable of avoiding physical disturbance by moving deeper into the sediment (e.g. Galéron et al. 2001). This could explain our results for the benthic fauna, but for calanoids rough hydrodynamic conditions could have enhanced mortality. Most of the above benthic taxa were designated as emergers by our statistical analyses. Thus our results confirm Thistle's (2003) conclusion that energetic flows suppress emergence. This view is moreover supported by the strong interannual variation found in the present study, i.e. swimmer fluxes were much lower in the year of energetic flows. Of the 10 taxa for which the statistical analyses produced no information, 5 (i.e. the miraciids SP1121 and the argestids SP12, SP14, SP15 and SP19) were absent in that year, perhaps indicating that they, too, were emergers.

\section{CONCLUSIONS}

This investigation, based on an often overlooked sampling technique, produced the most comprehensive time series of hyperbenthos (meiobenthos) ever conducted in the deep sea. In a single study, most of the dispersal mechanisms, both by passive erosion/ suspension or active emergence, previously reported for intertidal and shallow-water benthic organisms were encountered at $2347 \mathrm{~m}$ depth in the NW Mediterranean. The present study has led to new insights on the behaviour of deep-dwelling species, most of which have not yet been described, particularly within the typical deep-sea family Argestidae, some of which actively perform emergence. Some deep-sea species displayed a clear and rapid population growth in response to pulses of organic-rich detritus to the seafloor, a response that has never been shown before for deep-sea meiobenthic copepods. Moreover, our results underline the highly dynamic nature of deepsea meiofauna populations, which could, in part, explain the (absence of) temporal variability generally observed in sediment communities. Overall, the present study emphasizes the remarkable similarities in the general processes, whether physical or biological, between coastal and deep-sea environments.

Acknowledgements. This work was part of the French JGOFS program funded by the CNRS/INSU (France). L.G.G. thanks the officers and crews of RV 'Professeur George Petit' and 'Tethys II', as well as the technical team from EEP/LEP IFREMER for their assistance at sea. She gratefully acknowledges P. Crassous for performing the chemical analyses and P. Martinez Arbizu for advice on taxonomy.

\section{LITERATURE CITED}

Aller JY (1989) Quantifying sediment disturbance by bottom currents and its effect on benthic communities in a deepsea western boundary zone. Deep-Sea Res Part A 36: 901-934

Bell SS, Hicks GRF, Walters K (1988) Active swimming in meiobenthic copepods of seagrass beds: geographic comparisons of abundance and reproduction characteristics. Mar Biol 98:351-358

Bell SS, Hicks GRF, Walters K (1989) Experimental investigations of benthic reentry by migrating meiobenthic copepods. J Exp Mar Biol Ecol 130:291-303

Billett DSM, Bett BJ, Reid WDK, Boorman B, Priede IG (in press) Long-term change in the abyssal NE Atlantic: the 'Amperima Event' revisited. Deep Sea Res Part II doi: 10.1016/j.dsr2.2009.02.001

Boxshall GA, Halsey SH (2004) An introduction to copepod diversity. The Ray Society, London

Bühring SI, Christiansen B (2001) Lipids in selected abyssal benthopelagic animals: links to the epipelagic zone? Prog Oceanogr 50:369-382

> Drazen JC, Baldwin RJ, Smith KL Jr (1998) Sediment community response to a temporally varying food supply at an abyssal station in the NE Pacific. Deep-Sea Res Part II 45: 893-913

Gage JD, Tyler PA (1991) Deep-sea biology: a natural history of organisms at the deep-sea floor. Cambridge University Press, Cambridge

Galéron J, Sibuet M, Vanreusel A, Mackenzie K, Gooday AJ, Dinet A, Wolff GA (2001) Temporal patterns among meiofauna and macrofauna taxa related to changes in sediment geochemistry at an abyssal NE Atlantic site. Prog Oceanogr 50:303-324

Gardner WD, Richardson MJ (1992) Particle export and resuspension fluxes in the western north Atlantic. In: Rowe GT, Pariente V (eds) Deep-sea food chains and the global carbon cycle. Kluwer, Dordrecht, p 339-364

Giere O (2009) Meiobenthology. The microscopic fauna in aquatic sediments, 2nd edn. Springer, Berlin

> Gooday AJ (1988) A response by benthic foraminifera to phytodetritus deposition in the deep sea. Nature 332:70-73

> Gooday AJ (2002) Biological responses to seasonally varying fluxes of organic matter to the ocean floor: a review. J Oceanogr 58:305-332

Guidi-Guilvard LD (2002) DYFAMED-BENTHOS, a long time-series benthic survey at 2347-m depth in the NW Mediterranean: general introduction. Deep-Sea Res Part II 49:2183-2193

> Guidi-Guilvard LD, Buscail R (1995) Seasonal survey of metazoan meiofauna and surface sediment organics in a non- 
tidal turbulent sublittoral prodelta (northwestern Mediterranean). Cont Shelf Res 15:633-653

Hagerman GM, Rieger RM (1981) Dispersal of benthic meiofauna by wave and current action in Bogue Sound, North Carolina, USA. PSZNI: Mar Ecol 2:245-270

Hargrave BT, von Bodungen B, Conover RJ, Fraser AJ, Phillips G, Vass WP (1989) Seasonal changes in sedimentation of particulate matter and lipid content of zooplankton collected by sediment trap in the Arctic Ocean off Axel Heiberg Island. Polar Biol 9:467-475

Hicks GRF, Coull BC (1983) The ecology of marine meiobenthic harpacticoid copepods. Oceanogr Mar Biol Annu Rev 21:67-175

Higgins RP, Thiel H (1988) Introduction to the study of meiofauna. The Smithsonian Institution Press, Washington, DC

Huys R, Gee JM, Moore CG, Hamond R (1996) Marine and brackish water harpacticoid copepods. Part 1. In: Barnes RSK, Crothers JH (eds) Synopses of the British fauna, No. 51. Field Studies Council, Shrewsbury

Iken K, Brey T, Wand U, Voigt J, Jungsham P (2001) Food web structure of the benthic community at the Porcupine Abyssal plain (NE Atlantic): a stable isotope analysis. Prog Oceanogr 50:383-405

Kalogeropoulou V, Bett BJ, Gooday AJ, Lampadariou N, Martinez Arbizu P, Vanreusel A (in press) Temporal changes (1989-1999) in deep-sea metazoan meiofaunal assemblages on the Porcupine Abyssal Plain, NE Atlantic. DeepSea Res Part II doi:10.1016/j.dsr2.2009.02.002

Karl DM, Knauer GA (1989) Swimmers: a recapitulation of the problem and a potential solution. Oceanography 2:32-35

Karl DM, Bates N, Emerson S, Harrison PJ and others (2003) Temporal studies of biogeochemical processes determined from ocean time-series observations during the JGOFS Era. In: Fasham MJR (ed) Ocean biogeochemistry. The role of the ocean carbon cycle in global change. Springer, Berlin, p 239-267

Khripounoff A, Vangriesheim A, Crassous P (1998) Vertical and temporal variations of particle fluxes in the deep tropical Atlantic. Deep-Sea Res Part I 45:193-216

Lampitt RS (1985) Evidence for the seasonal deposition of detritus to the deep-sea floor and its subsequent resuspension. Deep-Sea Res Part A 32:885-897

Lampitt RS, Wishner KF, Turley CM, Angel MV (1993) Marine snow studies in the Northeast Atlantic Ocean: distribution, composition and role as a food source for migrating plankton. Mar Biol 116:689-702

Lampitt RS, Newton PP, Jickels TD, Thomson J, King P (2000) Near-bottom particle flux in the abyssal northeast Atlantic. Deep-Sea Res Part II 47:2051-2071

Lampitt RS, Bett BJ, Kiriakoulakis K, Popova EE, Ragueneau O, Vangriesheim A, Wolff GA (2001) Material supply to the abyssal seafloor in the Northeast Atlantic. Prog Oceanogr 50:27-63

Lochte K (1992) Bacterial standing stock and consumption of organic carbon in the benthic boundary layer of the abyssal North Atlantic. In: Rowe GT, Pariente V (eds) Deep-sea food chains and the global carbon cycle. Kluwer, Dordrecht, p 1-10

Marty JC (2002) The DYFAMED time-series program (French-JGOFS). Deep-Sea Res Part II 49:1963-1964

Mees J, Jones MB (1997) The hyperbenthos. Oceanogr Mar Biol Annu Rev 35:221-255

Palmer MA (1988) Dispersal of marine meiofauna: a review and conceptual model explaining passive transport and active emergence with implications for recruitment. Mar Ecol Prog Ser 48:81-91

Rakotomalala R (2005) TANAGRA: un logiciel gratuit pour l'enseignement et la recherche. Actes des cinquièmes journées Extraction et Gestion des Connaissances EGC'2005, Rev Nouvel Technol Inform (E-3) 2:697-702

Seiler D, Brandt A (1997) Seasonal occurrence of planktic crustacea in sediment trap samples at three depth horizons in the Greenland Sea. Polar Biol 17:337-349

Shanks AL, Edmondson EW (1990) The vertical flux of metazoans (holoplankton, meiofauna, and larval invertebrates) due to their association with marine snow. Limnol Oceanogr 35:455-463

Shanks AL, Walters K (1997) Holoplankton, meroplankton, and meiofauna associated with marine snow. Mar Ecol Prog Ser 156:75-86

Smith KL Jr, Carlucci AF, Jahnke RA, Craven DB (1987) Organic carbon mineralization in the Santa Catalina Basin: benthic boundary layer metabolism. Deep-Sea Res Part A 34:185-211

Smith KL Jr, Baldwin RJ, Karl DM, Boetius A (2002) Benthic community responses to pulses in pelagic food supply: North Pacific Subtropical Gyre. Deep-Sea Res Part I 49:971-990

Soetaert K, Herman PMJ, Middelburg JJ (1996) Dynamic response of deep-sea sediments to seasonal variations: a model. Limnol Oceanogr 41:1651-1668

Steinberg DK, Pilskaln CH, Silver MW (1998) Contribution of zooplankton associated with detritus to sediment trap 'swimmer' carbon in Monterey Bay, California, USA. Mar Ecol Prog Ser 164:157-166

Thiel H, Pfannkuche O, Schriever G, Lochte K and others (1989) Phytodetritus on the deep-sea floor in a central ocean region of the Northeast Atlantic. Biol Oceanogr 6:203-239

> Thistle D (2003) Harpacticoid copepod emergence at a shelf site in summer and winter: implications for hydrodynamic and mating hypotheses. Mar Ecol Prog Ser 248:177-185

Thistle D, Sedlacek L (2004) Emergent and non-emergent species of harpacticoid copepods can be recognized morphologically. Mar Ecol Prog Ser 266:195-200

Thistle D, Ertman SC, Fauchald K (1991) The fauna of the HEBBLE site: patterns in standing stock and sedimentdynamic effects. Mar Geol 99:413-422

> Thistle D, Sedlacek L, Carman KR, Fleeger JW, Barry JP (2007) Emergence in the deep sea: evidence from harpacticoid copepods. Deep-Sea Res Part I 54:1008-1014

Turner JT (1986) Zooplankton feeding ecology: contents of fecal pellets of the cyclopoid copepods Oncaea venusta, Corycaeus mazonicus, Oithona plumifera, and O. simplex from the northern Gulf of Mexico. PSZNI: Mar Ecol 7: 289-372

> Uye S, Sano K (1998) Seasonal variations in biomass, growth rate and production rate of the small cyclopoid copepod Oithona davisae in a temperate eutrophic inlet. Mar Ecol Prog Ser 163:37-44

Vanreusel A, Cosson-Sarradin N, Gooday AJ, Paterson GJL, Galéron J, Sibuet M, Vincx M (2001) Evidence for episodic recruitment in a small opheliid polychaete species from the abyssal NE Atlantic. Prog Oceanogr 50:285-301

> Walters K (1991) Influences of abundance, behavior, species composition, and ontogenetic stage on active emergence of meiobenthic copepods in subtropical habitats. Mar Biol 108:207-215

Willis K, Cottier F, Kwasniewski S, Wold A, Falk-Petersen S (2006) The influence of advection on zooplankton community composition in an Arctic fjord (Kongsfjorden, Svalbard). J Mar Syst 61:39-54

Wishner KF (1980) Aspects of the community ecology of deepsea, benthopelagic plankton, with special attention to gymnopleid copepods. Mar Biol 60:179-187 